\title{
2236 流れ負荷による内皮細胞の形態と細胞表面のせん断応力の変化
}

\section{Changes in Endothelial Cell Shape and Shear Stress on the Cell Surface during Flow Exposure}

\author{
○正 福島 修一郎 (慶大理工院) \\ 正 谷下一夫（慶大理工） \\ 正 藤岡 秀樹（英インペリアルカレッジ）
}

Shuichiro FUKUSHIMA, Keio University, 3-14-1 Hiyoshi, Kohoku-ku, Yokohama

Hideki FUJIOKA, Imperial College, UK.

Kazuo TANISHITA, Keio University

Key Words: Endothelial Cell, Cell Morphology, Shear Stress

\section{1. はじめに}

内皮細胞は負荷される流れによって形態を変化させる機 能を有している. in vivoの形状は血流に依存して血管の部位 により異なっており, 血流の変化に対応した形態変化も起こ る. in vitro でも類円形の培養細胞が流れ負荷により伸長して 流れ方向に配向することが確認されている. 細胞の3 次元形 状を考慮した細胞近傍の微視的流れ場の解析結果 ${ }^{(1-4)}$ は, こ のような形態変化が細胞表面に負荷されるせん断応力を減 少させる適応反応であること示唆している。 しかし, 形態変 化過程で微視的流れ場がどのように変化し, 最終的な適応的 形状を実現しているかは明らかになっていない，特に，個々 の細胞ごとにみた場合の形態変化や応力分布が不均一であ ることが適応メカニズムの解秎を困難にしている. そこで本 研究では, 形態変化過程の培養細胞の 3 次元形状を測定し, その形状をもとに数值計算で細胞近傍の微視的流れ場を求 めて細胞表面のせん断応力分布がどのように変化するかを 個々の細胞レベルで明らかにした。

\section{2. 方法}

\section{1 梱胞形状測定}

ウシ大動脈由来の内皮細胞(Cell Systems)を 10\%ウシ胎児 血清(FBS, JRH Biosciences) と抗生物質(Antitiotic-Antimycotic, GIBCO)を含む培盖液(DMEM, GIBCO)で培養した，平行平板 流路に播種してコンフルエントなった細胞(継代数 5～9)に 細胞層を平坦とみなした場合に $1.5 \mathrm{~Pa}$ のせん断応力となる定 常流 72 時間まで負荷し, 1 時間おきに細胞の位相差像を記 録して同一細胞集団を追跡した。

形態変化が顕著だった流れ負荷開始後 $24,30,36$ 時間の 3 時刻で共焦点レーザ顕微鏡を用いて細胞の3 次元形状を測定 した ${ }^{(4)}$. 細胞断層像は, $1 \mathrm{mg} / \mathrm{ml}$ Fluorescein isothiocyanate Dextran（FITC-Dextran, $2000 \mathrm{kDa}$; SIGMA）を含む培養液を還 流した状態で，共焦点レーザ顕微鏡 (MRC-600; Bio-Rad Laboratories)を用いて $0.3 \mu \mathrm{m}$ 間隔で記録した。断層像の輪郭 を抽出して等高線図を作成し，等間隔の格子点上で細胞の高 さを補間して細胞表面形状を立体再構筑した。

\section{2 流れ場の数值計算}

支配方程式は 3 次元非圧縮性ニュートン流体の Navier-Stokes 式を用いた，計算は，代表長さを計算領域の高 さ，代表速度を上面に打ける一定速度とした無次元量で行っ たこのときのレイノルズ数は 5.1 となる.計算領域内(Fig. 1) でクエット流を実現し，底面が平坦なときに壁せん断応力が $1.5 \mathrm{~Pa}$ となるように流入面で線形な速度分布を与えた。底面 には形状を測定した 60 から 70 の細胞を配置し, 細胞表面で 滑りなし条件を適用した。.上面では線形な速度勾配から求め た流速を与えた。側面では対称条件を適用した．細胞層の周 囲には平面を確保したため，流入面，流出面，側面の流れ場
に対する影響はなかった. 計算領域の高さは底面の壁せん断 応力が領域高さに依存しなくなる $50 \mu \mathrm{m}$ とした. 計算格子は 境界適合座標系のスタガード格子 $(240 \times 160 \times 60)$ を用いた。 細胞表面の格子点間陽は $1.25 \mu \mathrm{m}$ で, 高さ方向には細胞表面 に近いほど格子点が密になるようにした。計算アルゴリズム はSIMPLER 法を用いた。せん断応力は細胞表面に 1 番近い 圧力格子点上に流速を補間して線形な速度勾配から計算し た.

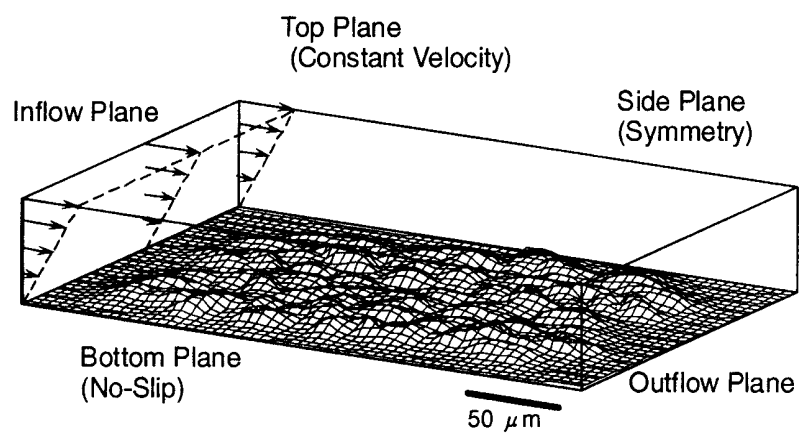

Fig. 1 Computational Domain

\section{3. 結果および考案}

細胞形状は流れ負荷前は類円形で方向性がなかったが, 流 れ負荷後 24 時間以降で伸長が顕著となり，30 時間以降で配 向角 (巨視的流れ方向と細胞長軸がなす角度) の分布が変化 した. 48 時間以降では大部分の細胞が巨視的流れ方向に配向 して 72 時間まで細胞形状に大きな変化はなかった. Fig. 2 に 流れ負荷後 $24,30,36$ 時間の等高線図を示す. 位相差像か ら各時刻で同一細胞を同定してラベルをつけた. 13 個の細胞 の高さの平均值は $24,30,36$ 時間でそれぞれ $3.3 \pm 0.7 \mu \mathrm{m}$, $3.4 \pm 0.5 \mu \mathrm{m}, 3.0 \pm 0.4 \mu \mathrm{m}$ でだった. 30 時間では高さが減少 する細胞と増加する細胞はほほ同数であるが, 36 時間では減 少する細胞の割合が増えて, 平均値の増加量が大きい細胞は 1 個（Cell\#7）のみだった。

細胞表面のせん断応力ベクトルを Fig. 3 に示す. 13 個の細 胞全体のせん断応力の平均值は 24 時間, 30 時間, 36 時間で それぞれ $1.07 \pm 0.31,1.02 \pm 0.33,1.01 \pm 0.34$ となり, 最大 值は $2.06,1.94,2.21$ となった. 時間経過とともに 1 以下の 低せん断応力が負荷されている領域の割合が増加した. せん 断応力の大きさは細胞の高さに依存しており, 最高点では巨 視的なせん断応力の 2 倍以上になる細胞もあった。同じ高さ で比較すると細胞側面のほうが上流と下流側よりせん断応 力は大きかった. 細胞頂上付近でせん断応力が最大となるが, 必ずしも高さの最高点で応力が最大となるわけではなかっ た，せん断応力の向きは, 細胞の核付近の高い部分を回り込 
むような流れに対応しており，巨視的な流れ方向となす角度 は最大で $60^{\circ}$ になるところもあった.

細胞ごとにみるとせん断応力が減少する細胞の数が時間 経過とともに増加した. 個々の細胞が時々刻々のせん断応力 を受容して適応的な形態変化をすると考えることもできる が, 全ての細胞でせん断応力が減少するわけではなく (30h-Cell\#1,3,4,5,6,36h-Cell\#3,6,7,8,9), 36 時間のほうが24 時 間よりも大きい細胞もあった(Cell\#3,4,6,7). せん断応力が増 加する形態変化をする細胞もあるにもかかわらず，せん断応 力が減少する細胞数が時間経過とともに増加して細胞層全 体の平均值が減少する要因として, 細胞が移動するときの方 向性が挙げられる.流れ負荷後は単純に流れにのって下流に 移動するわけではなくランダムに移動するが, 30 時間以降は

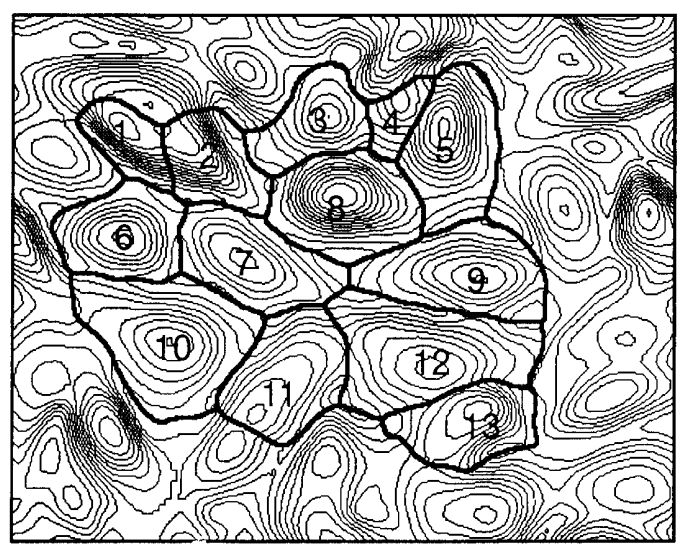

(a) $24 \mathrm{~h}$

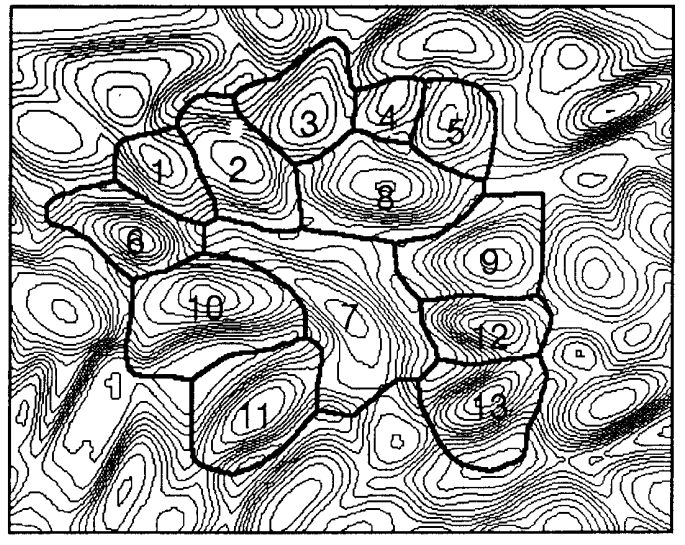

(b) $30 \mathrm{~h}$

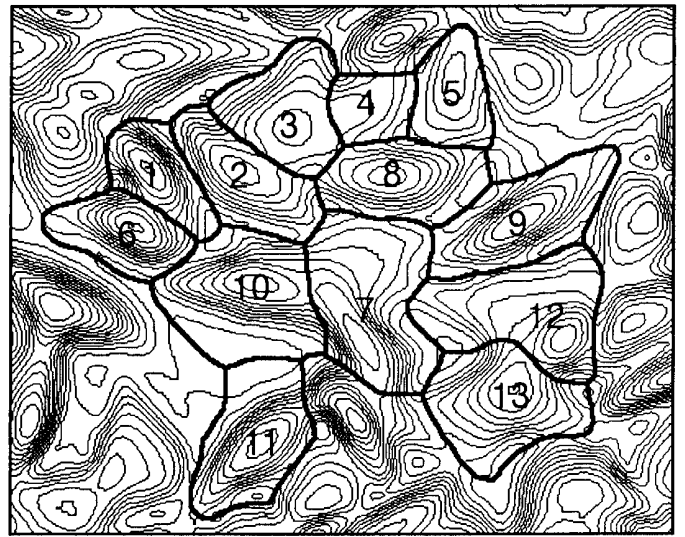

(c) $36 \mathrm{~h}$

$1 \overline{0 \mathrm{~m}}$

Fig. 2 Contour Map of Endothelial Cells (line Interval: $0.5 \mu \mathrm{m}$ )
下流側への移動量大きくなり，その方向に伸長する場合が多 かった. 細胞が伸伸長すると上流側の細胞表面の傾きが小さ くなってせん断応力は減少する傾向がある．周囲の細胞との 相互作用で移動方向が流れ方向に限定された結果として流 れ方向に配向した形態になると考えられる。

\section{参考文献}

1. Satcher, R.L. et al., J. Biomech. Eng., 114, pp.309-316 (1992).

2. Barbee, K.A. et al., Am. J. Physiol., 268, pp.H1765-1772 (1995).

3. Yamaguchi, T. et al., J. Biomech., 33, pp.115-126 (2000).

4. Fukushima, S. et al., JSME Int. J. C, 44, pp. 972-981 (2001)

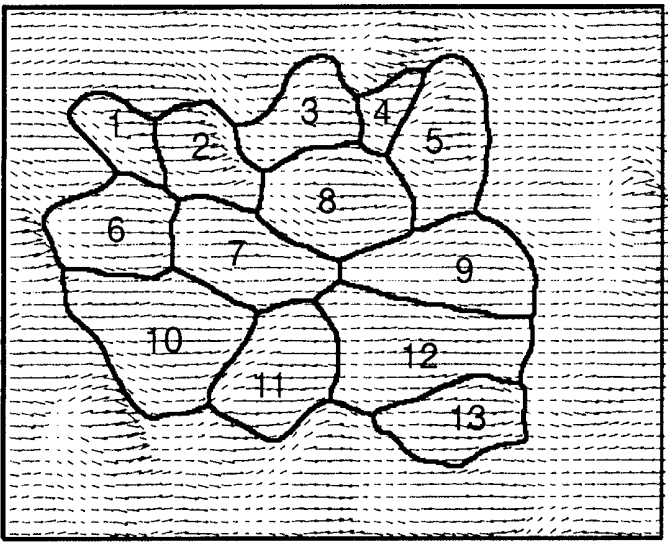

(a) $24 \mathrm{~h}$

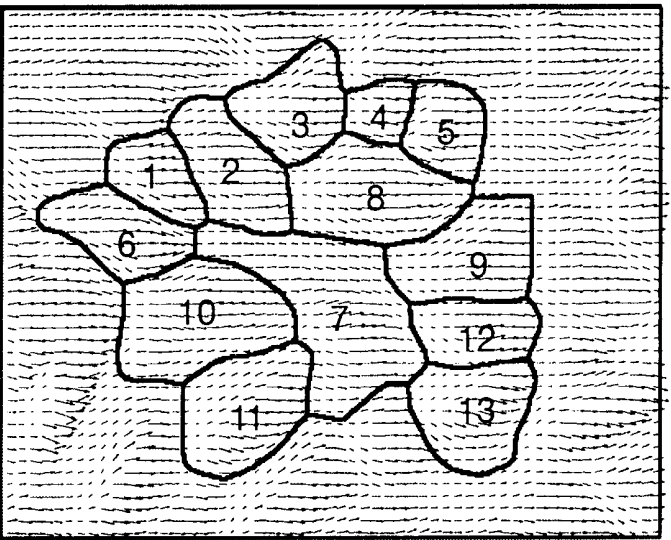

(b) $30 \mathrm{~h}$

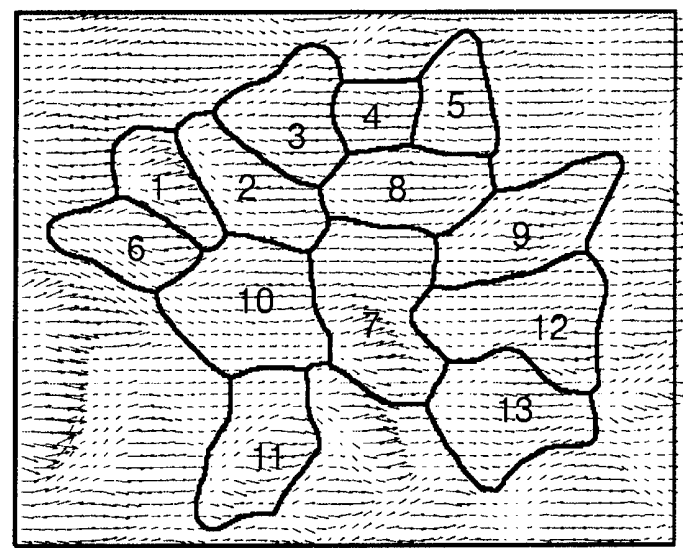

(c) $36 \mathrm{~h}$

Fig. 3 Wall Shear Stress Vector 